\title{
Exploring the (missed) connections between digital scholarship and faculty development: a conceptual analysis
}

Open Access

Juliana Elisa Raffaghelli

Correspondence: jraffaghelli@gmail.com

Department of Educational Sciences and Psychology, University of

Florence, Florence, Fl, Italy

\begin{abstract}
The aim of this paper is to explore the relationship between two research topics: digital scholarship and faculty development. The former topic drives attention on academics' new practices in digital, open and networked contexts; the second is focused on the requirements and strategies to promote academics' professional learning and career advancement. The research question addressing this study is: are faculty development strategies hindered by the lack of a cohesive view in the research on digital scholarship? The main assumption guiding this research question is that clear conceptual frameworks and models of professional practice lead to effective faculty development strategies. Through a wide overview of the evolution of both digital scholarship and faculty development, followed by a conceptual analysis of the intersections between fields, the paper attempts to show the extent on which the situation in one area (digital scholarship) might encompass criticalities for the other (faculty development) in terms of research and practices. Furthermore, three scenarios based on the several perspectives of digital scholarship are built in order to explore the research question in depth. We conclude that at the current state of art the relationship between these two topics is weak. Moreover, the dialogue between digital scholarship and faculty development could put the basis to forge effective professional learning contexts and instruments, with the ultimate goal of supporting academics to become digital scholars towards a more open and democratic vision of scholarship.
\end{abstract}

Keywords: Digital scholarship, Information science, Educational technology, Interdiscipline, Open science

\section{Introduction}

The concept of Digital Scolarship was coined early in the 2000 decade to characterize the scholars' professional practices linked to digital environments and tools (Andersen \& Trinkle, 2004; Ayers, 2004).

While it has been defined generally as the use of digital evidence, methods of inquiry, research, publication and preservation to achieve scholarly and research goals (Rumsey, 2011 cited on Wikipedia), a first exploration of the literature yields hundreds of definitions that make the issue to appear elusive. The terms adopted span from e-scholarship (Borgman, 2008), digital scholarship (Costa, 2013; Pearce, Weller, Scanlon, \& Kinsley, 2010; Scanlon, 2014; Weller, 2012), networked scholarship

(c) The Author(s). 2017 Open Access This article is distributed under the terms of the Creative Commons Attribution 4.0 International License (http://creativecommons.org/licenses/by/4.0/), which permits unrestricted use, distribution, and reproduction in any medium, provided you give appropriate credit to the original author(s) and the source, provide a link to the Creative Commons license, and indicate if changes were made. 
(Quan-Haase, Suarez, \& Brown, 2014; B. E. Stewart, 2015a; Veletsianos \& Kimmons, 2012b), open scholarship (Garnett \& Ecclesfield, 2012; George Veletsianos, 2015) and research 2.0. (Esposito, 2017; Oliveira et al., 2017). Moreover, the above mentioned terms often refer to different research issues and problems, like the cyberinfrastructures' affordances endowing scholars to become more "digital", like institutional repositories supporting Open Access (Borgman, 2007; Cox, 2016); or the uses and practices linked to open and social media as Facebook and Twitter as a mean to become a "social and networked" scholar (Manca \& Ranieri, 2016; Veletsianos, 2012; George Veletsianos \& Kimmons, 2016). The underlying values motivating these studies are also diversified: while some of them advocate for the need of opening up science, paying particular attention to the public nature of science and its products (Den Besten, David, \& Schroeder, 2010; Pontika, Knoth, Cancellieri, \& Pearce, 2015), others focus the scholars' struggle against power within the academia and their attempts to shape the own professional identity (Costa, 2014; Hildebrandt \& Couros, 2016). Furthermore, the nature of openness in science as the emerging paradigm for scholars to communicate and connect to the external world beyond the "academic ivory tower", has been found to be based on several schools of thought (Fecher \& Friesike, 2013). More recently, a systematic review of the literature and a study on bibliometric maps (Raffaghelli, Cucchiara, Manganello, \& Persico, 2016a) led the authors to conclude that within the topic of digital scholarship there are several disciplines that contribute with scarce awareness of their specific methodological approaches and the underlying conceptual frameworks adopted.

If the concept of Digital Scholarship is fuzzy and covers in a fragmented way different phenomena, we can expect this problem to impact not only on further research, but also over the applied science. Of particular interest is the case of faculty development, namely, the pedagogies that could address professional learning processes to know, to do and to become a digital scholar. Scholars' professional learning has been characterized by another convergent field of research and practice, namely, faculty development. In fact, faculty development can be defined as the practices and environments promoting scholars' skills to advance in their careers, to perform their role with quality and excellence, and to innovate within their contexts of professional engagement (Boyer, 1990; Braxton, Luckey, \& Helland, 2002). However, effective faculty development has as main requirement a good recognition of contents and methods for professional learning (Grover, K. S. Walters. S. R. C, 2016), something that Digital Scholarship could not be able of providing at its current state of advancement.

Therefore, the aim of this paper is to explore the relationship between two research topics: digital scholarship and faculty development, attempting to show a) the rather unexplored and intuitive relationships between the two fields and b) the way in which these missed connections could affect further research and practices addressing professional development for digital scholarship. Hence, the article attempts strengthen the dialogue between digital scholarship and faculty development as the base to forge effective professional learning contexts and instruments, with the ultimate goal of supporting academics to become digital scholars towards a more open and democratic vision of scholarship.

\section{Methodological approach}

Emerging topics of research require elaboration in order to configure constructs that give place to further empirical research. In social sciences and within them in 
educational research we frequently assist to scientific interests growing over the basis of changing societal conditions and problems. These give birth to case studies, exploratory research and/or best practices studies, and hence, to more structured, experimental approaches (Gorard, 2004; Gorard \& Cook, 2007). Instead, the exploration of research topics through several forms of literature review bring light on the directions of advancement of a research topic or field (Petticrew \& Roberts, 2006). In the cases where the topic is new or requires interdisciplinary attention, conceptual overviews of the topics under analysis followed by critical and reflective discussion can put the basis for more specific interventions aimed at formalizing frameworks, methods, and constructs to be empirically explored (Petticrew \& Roberts, 2006). In line with this, the current article undertakes a conceptual analysis addressed by the following research question: are faculty development strategies hindered by the lack of a cohesive view in the research on digital scholarship? The main assumption guiding this research question is that clear conceptual frameworks and models of professional practice (in digital scholarship) will lead to effective faculty development strategies (for digital scholarship). The conceptual analysis is carried out through three steps with their set of specific research questions:

a) The evolution and current state of digital scholarship as research topic. The main research question are faculty development strategies hindered by the lack of a cohesive view in the research on digital scholarship? is here explored through the subsidiary question is the current state of research on digital scholarship fragmentary? The answer is provided through the overview of the literature and aims at understanding how digital scholarship has evolved as topic of research, and to observe if (as we assumed) this evolution has been fragmentary. We will build on the work of Raffaghelli et al. (2016), that identified three main disciplinary perspectives of research on digital scholarship: Information Sciences and cyberinfrastructures, Digital Humanities, and Professional networked learning. We will analyse these three perspectives, from their conceptual foundations to the current trends of research to see whether there is a fragmentary composition.

b) The evolution and current state of faculty development as research topic. The main research question is here explored through the subsidiary question how is faculty development defined in the research and which are the requirements for effective faculty development practices? The answer is provided through the overview of the literature and aims at understanding the potential gaps that a fragmented vision of digital scholarship could left uncovered. An important assumption here is that the research advancements on digital scholarship are a crucial element to configure the ideal scenarios of professional performance and the approaches to implement professional development on the issue.

c) The analysis of intersections between the two research topics. The main research question is here explored through the subsidiary question how the fragmentary vision of digital scholarship could influence faculty development? The answer is provided through a critical discussion integrated with three scenarios of faculty development based on the several perspectives of digital scholarship. The scenarios should bring concrete elements to deepen on the assumptions made through the previous overview of the literature. 
In the conclusions, the overview and the connected discussion are wrapped up with remarks for future research and practices.

\section{The research on Digital Scholarship: separated worlds}

Digital scholarship disserved increasing interest from the research community of librarians from the beginning of 2000 along with the various transformations that library services faced through their progressive digitalization. Since the librarians had constantly collaborated with scholars in both searching scientific information as well as in cataloguing and supporting the visibility of scholarly results for career purposes, the topic was easily perceived as research problem (J. Cox, 2016; Zhao, 2014). Moreover, the Open Access movement gave an impressive input to librarianship to reflect on the own practices and services, that was immediately transferred to academics' practices. Digital scholarship in this field was defined as Building a digital collection of information for further study and analysis, creating appropriate tools for collection-building, creating appropriate tools for the analysis and study of collections, using digital collections and analytical tools to generate new intellectual products, creating authoring tools for these new intellectual products, either in traditional forms or in digital form (Palmer \& Cragin, 2008, p.196). Most contributions from Information and Library sciences emphasized the problems of librarians to support scholars' understanding and use of digital textual and multimedia collections; as well as the way scholars could enhance digital infrastructures to facilitate the academic endeavour (from searching documents to collaborate with other scholars). Last, but not least, the debate focused the way scholars could adopt digital facilities provided by libraries to increase reputation (Andersen, 2003; Holliman, 2010; Quigley, Neely, Parkolap, \& Groom, 2013; Zhao, 2014). This concern about infrastructures developed hand in hand with the debate on Open Access (Den Besten et al., 2010; Suber, 2009). The need of opening up science seemed to be in transition towards the fully accessible, public and participatory concept of science in and for society, where the initial concept of eScience (e for electronic) was developing into Open Science with its impact on scholarship (Ren, 2013). Research in this field also built on scientometrics to study power relationships, reputation and visibility of science, since the pioneering works of De Solla Price (1963), praised by the sociologists of science Merton and Garfield, (1986). In fact, the method showed through mathematical and statistical principles the relationships in science early studied by Merton (1942 [1979]). This important contribution was translated into the current trend analysing not only the power influences and the processes of reputation building through traditional citation networks (obtained through traditional, paid publishers and scientific databases); but also through the Open Access publications and repositories, the open web, and more recently by social media platforms, building emergent metrics or altmetrics (Roemer \& Borchardt, 2012). The altmetrics should support new reputation mechanisms for scholars (Jamali, Nicholas \& Herman, 2016) and new ways of developing collaboration and trust (Jamali et al., 2014) towards a more open and democratic concept of science and beyond "the invisible college" (a concept adopted by De Solla Price, quoted by Valente, 2003). However most debates in this area remained disconnected to a critical perspective for scientists' professional learning to be introduced to a fair-minded digital, networked and open science. The deep debate 
enacted by De Solla Price went far from research exploring more or less naïve approaches to organizing and delivering digital services for scholars (in the best of cases connected to Open Access, but in most cases inevitably linked to digitalized but still traditional science).

Furthermore, the problems in this area were soundly conceptualized by Christine Borgman (2007) in her influential book "Scholarship in the Digital Age: Information, Infrastructure and the Internet". In Borgman's contribution, the concept of digital scholarship was in tight connection with the debate about cyberinfrastructures supporting new forms of doing research and science, namely, eResearch and eScience, with the progressive digitalization of institutional infrastructures and the expected impact on scholars' practices to deal with information and communication processes, but went beyond these services to critically think how these cyberinfrastructures could reshape scholarly practices and production. Borgman's work doubtlessly arose from the deep-rooted information science field. However, she was critical with regard to the risks of technological determinism, namely, thinking of technological platforms as the only influencers of human behaviour and organizational change. The sociotechnical studies played a highly important role in this case (Borgman, 2007, p.42-43) by pushing her in an opposite, new direction with regard to the information sciences trend (analyzing infrastructure's building and the users' experiences within them). As Borgman explained: Librarianship tends to focus on methods of constructing organizational tools that reflect the world in the most authoritative manner, while recognizing that no organizational tool is static. Rather, it must be updated continuously, via consensus process, to maintain its currency and relevance. Sociotechnical studies, in contrast, tend to focus on how these representational tools construct the world, and how they both facilitate and constrain behavior (Borgman, 2007, p.43). She accomplished, in this sense, a first effort in a cross-disciplinary direction, bridging the debate on cyberinfrastructures with professional practice and institutional development.

In sum, the evolution of research in this field went in the direction of analysing the affordances and usage of cyberinfrastructures for the research flow as part of a scientific information life cycle (Borgman, 2007, p.229; Hernon, 1994): filtering/accessing, creating/using, modifying/authoring, indexing/organizing, storing/retrieving, distributing/networking the results of research as digital objects containing scientific information, and doing so across traditional cyberinfrastructures, open access repositories or social media. However, another strand within this disciplinary field attempted to analyse how scholars build trust, collaboration and reputation studying metrics based mostly on cross-citations and surveys.

In close connection with information sciences and library studies, a second strand of research emerged within the humanities in the cross-over with digital technologies, opening to a new field of research, that of "digital humanities"(Terras, Nyhan, \& Vanhoutte, 2013). As Terras et al. pointed out Digital Humanities as a term (...) provides a big tent for all digital scholarship in the humanities (2013, p.140). The scholars connected to this perspective worked intensely to define the boarders of theory and practices as a field of research (Unsworth, 2013), embraced the new forms of representation of cultural heritage, including history, arts and literature through the digital medium (Bentkowska-Kafel, 2013; Gardiner \& Musto, 2015; Kaltenbrunner, 2015). Moreover, the term encompassed the debate connected to the changing research 
methods and required professionalism in the humanities along an interdisciplinary dialogue with digital technologies (Klein, 2015). In sum, digital humanities seemed to be at the cross-over of the debate about digital scholarship, adding its "unease" but also providing clear examples of practice of digital scholarship (Flanders, 2013).

A last strand connected to the academics' professional learning and identity in the digital era emerged in tight connection with the educational technologies' research, by about 2010. The interest in the matter of digital scholarship spread in this research area since scholars contributing to it were interested in the complexities of the technological uptake by institutions and the users as socio-cultural shift encompassing professional practices, the connected learning ecologies and the impacts on professional identity (Pearce et al., 2010). Within this field the research was focused on scholars' struggle to do (practices) and to be (identity) in the changing context of higher education. In fact, scholars' were somehow pushed (in rather conflictive and contradictory ways) to keep the pace of innovations based on digital, open and networked contexts (Goodfellow, 2014; Scanlon, 2014; Weller, 2011). The conundrum of opening up science and education was thereby faced through the exploration of professional learning as process through which the scholar undergoes in her effort to be more open, more digital or more networked (Goodfellow, 2014). Moreover, the focus of research shifted from the objective usage of cyberinfrastructures to understand how the technological affordances might create new scenarios for practice encompassing a deontological reflection (Costa, 2014; Scanlon, 2014; Veletsianos \& Kimmons, 2012b). This approach aligned indeed with socio-technical studies going beyond technological determinism (Pearce et al., 2010).

For this group of researchers, the research problems relating Digital Scholarship were mostly connected with the adoption of unconventional cyberinfrastructures like social media to do and share research -social scholarship- (Greenhow \& Gleason, 2014; Manca \& Ranieri, 2016a; Veletsianos, 2012); the collaboration between researchers to co-create content in more fluid processes of work that connect research with interdisciplinary interactions, teaching and dissemination (Garnett \& Ecclesfield, 2012; Veletsianos \& Kimmons, 2012a); engaging public audiences in the making of science, by extending the forms of participation along the research process (Grand, Wilkinson, Bultitude, \& Winfield, 2012). The whole debate was connected to the need to improve scholars' literacy to participate in digital, networked and open contexts of scholarship (Goodfellow \& Lea, 2013; Veletsianos \& Kimmons, 2012b). Moreover, in this research community it was possible to observe a strong reference to Boyer's model (Boyer, 1990) on the academic profession. In fact, the need for reconsidering the academic profession has been an issue for research since Boyer's "new priorities for the professoriate" in the '90s (Boyer, Moser, Ream, \& Braxton, 2015; Teichler, Arimoto, \& Cummings, 2013). Boyer pointed out that a new scholarship should be based in four functions: Discovering (creating new knowledge through research), Integration (interaction across disciplinary lines to construct new research approaches to social problems), Application (transacting with the society to use academic knowledge), Teaching (use academic knowledge to educate future generations of practitioners and scholars). Therefore, Digital Scholarship's perspective for this group (see for example Greenhow \& Gleason, 2014; Weller, 2011) showed that Boyer's 4 dimensions were being accelerated and transformed by: a) openness in both science and the research activities, b) open learning and teaching; c) networking, as the new professional ways of collaboration 
across geographical and institutional frontiers based on the affordances provided by social networks and the Web 2.0. However, in spite of the interconnectedness between digitality with openness and networking, digital practices rather follow traditional schemes (Goodfellow, 2014). For Esposito (2013), scholarly practices are caught in the middle of being digital/open or traditional, aligning this conception with the visitors/ residents' idea of using digital tools or living within digital spaces (White \& Cornu, A. Le, 2011). For Costa (2014) scholars are reinventing themselves online along different episodes of "outcasts on the inside" for deploying professional identity as digital scholar come at a price. As she expresses "The difference between the field and the habitus individuals bring to it leads to misrecognition of practice... ambivalence between the university world and research participants' intellectual journeys results is a disjoined sens of identity and predisposition to symbolic revolutions" (Costa, op.cit. 207). Moreover, Stewart (2015) equates traditional practices to doing research in a "scarce context" whereas "...In the process of using, sharing, and contributing to this abundant and ever-renewing body of resources and ideas, scholars become more visible to each other and their areas of interest more legible".

With regard to the methodological approaches in this field, while there were also extensive studies covering the way scholars adopted social media through surveys (Manca \& Ranieri, 2017), most studies in this field were based on qualitative methods observing and making thick descriptions and narratives on scholars' forms of approaching open social media, particularly blogging (Kjellberg, 2014) and microblogging with Twitter (Stewart, 2015; Veletsianos, 2012; Veletsianos \& Kimmons, 2016). Some of these studies adopted critical and post-structural theoretical frameworks like Bourdieu's habitus (Costa, 2013, 2014) Foucault's "power and technologies of the self" (Hildebrandt \& Couros, 2016), or Bakhtin's "chronotopes" (Esposito, Sangrà, \& Maina, 2013) aiming at showing how transition from tradition and the science in the "ivory tower" is in open and painful contradiction with the making of the scholar's identity as open, networked and digital.

To sum up, this research strand focused not only how the scholars behave in the digital, networked and open contexts of practice, but it worked out the tensions and contradictions that lead academics to act creatively to align values and practices within the making of their professional identity.

We must mention at this point cross-fertilization between trends. The first one regards the highly cited work of Boyer, which has been extensively adopted as model of scholarship. Almost all consulted studies in the field of educational technologies elaborate on Boyer's model, starting from Weller's work (2011); a good number of papers from the information science area take into consideration this author (Raffaghelli et al., 2016). Another author that we should recognize as "boundary crossing" is surely Borgman (2007) whose influencial work (mentioned above) has introduced the problem of digital scholarship for information sciences but also acknowledged the socio-technical studies as another perspective explaining the creative relationship between scholars and cyerinfrastructures. Building on the concept of "literacies" for the digital university, Goodfellow, (2013) makes Borgman (2007) and Weller (2011) to dialogue, in an attempt to understand the concepts emerging from these two works to define digital and academic literacies. More recently, the topic of professional identity studied in the field of educational technologies has been 
connected to reputation (Stewart, 2014; G. Veletsianos \& Stewart, 2016); and from the side of information science studies reputational mechanisms have been analysed under the lens of Boyer's model for professional development.

However, there are tensions that a more interdisciplinary and cohesive approach could solve. For example, the value of social media platforms to promote new forms of communicate science and of opening science in more participatory and informal ways, that is often assumed in many of the educational technologists' works is highly contested by many groups of librarians. These lasts see social media platforms and their business models as potentially hazardous for a public and democratic science. Moreover, this last group point out the unfair competition social media (with their appealing and user-friendly interface) generate against institutional repositories as public funded and hence safer for public dissemination of science (Hall, 2015).

Wrapping up, the depicted situation let us only recognize the peak of the iceberg, understanding some of the research subtopics and problems, the methodological approaches and the disciplinary contributions within the broad issue of digital scholarship. However, the analysis of the literature in an attempt to characterize the three strands of research shows that the connections between the several perspectives are still far from come into being.

\section{The undefined panorama of DS and its impact on faculty development Understanding Faculty development}

Faculty development has been frequently adopted to refer to all sort of educators engaged in higher education, particularly at undergraduate level. The term was coined to characterize teaching skills' frameworks as well as the strategies to develop them within the professional context and along professional life cycle. While it became a standalone area of research and practice, it evolved hand in hand with the deep debate on teachers' professional development (TPD) of any educational level and the perceived need of continuously support their processes of professionalization (Hendriks, Luyten, Scheerens, Sleegers, \& Steen, 2010; Twining, Raffaghelli, Albion, \& Knezek, 2013). Moreover, a high number of contributions in the field came from the research area of medical education (Steinert et al., 2016). The topics covered within studies on faculty development regarded mainly the effectiveness of professional development programs (Centra, 1978; Simon \& Pleschová, 2013) analysing not only the academics' perceptions and effective changes on their professional practices but also on students' learning (Guskey \& Yoon, 2009).

The analysis focused differentially duration, format, or target group of the several faculty development actions (Stes, Min-Leliveld, Gijbels, \& Van Petegem, 2010). The strategies related mainly specific skills development like internationalization and intercultural education, management, curriculum development, quality teaching, teaching innovations, or online teaching; but also covered professional development methods like workshops, problem-based learning, professional networks, action research and reflection on practice (Amundsen \& Wilson, 2012).

Within this context, the problem of scholars' skills and literacies needed to work within digital spaces has become a specific area of interest. An impressive amount of literature mainly analysed faculty development for online teaching (Meyer, 2014) 
exploring the barriers and enablers of elearning (Singh \& Hardaker, 2014). Recently, frameworks for professional development relating to open education have been proposed (Nascimbeni \& Burgos, 2016). However, the majority of studies in faculty development in general and in the area of online teaching specifically have been criticized by the lack of theoretical or conceptual frameworks on professional learning underpinning practice (Webster-Wright, 2009). In this regards, there have been few exceptions citing adult learning theories like those of transformative learning by Mezirow, andragogy by Knowles, or reflective practice by Argyris \& Schon (WebsterWright, 2009, Amundsen \& Wilson, 2012; Meyer, 2014). Moreover, the outcome vs. the process approach in the reviewed literature could be deemed uneven. Some studies focus the skills' acquisition or the students' achievements as proof of effectiveness (Bahar-Ozvaris, Aslan, Sahin-Hodoglugil, \& Sayek, 2004; Cole et al., 2004), other focus on the process of active professional learning as part of changing practices, and a last group consider how the new professional skills could modify the professional and organizational context, being the academics social and situated learners (Boud, 1999; Cox, 2004).

For Amundsen and Wilson (2012) the right questions to address faculty development are How are educational development practices designed? and What is the thinking underpinning the design of educational development practice? (Amundsen \& Wilson, 2012, p.91). We should consider at this point that the lack of a vision able of answering these two questions is the main problem not only to design a program for professional learning, but also to understand whether the achievements envisaged by a professional development programme took place. As Evans explained, whilst professional culture may be interpreted as shared ideologies, values and general ways of and attitudes to working [...] professionalism seems generally to be seen as the identification and expression of what is required and expected of members of a profession (Evans, 2008, p.7).

Professional development requires hence the acknowledgement of a professional culture within an institutional culture of development, as dynamic and lifelong learning process of the individual towards a community. To this regard, the efforts to train professionals are based on an overarching, big picture of a professional area, which encompasses practices and a professional identity. This way of conceiving professional learning implies at operational level complex systems, based on the following dimensions:

1. A framework of competences and scenarios of expertise with middle stages of development (from novice to expert), that are closely connected not only with the developmental processes within the organization but also the society;

2. institutional strategies and policies connected to developmental processes within the organization, that in time acknowledge the existence of embedded professional communities with their values, identity and practices (Vescio, Ross, \& Adams, 2008; Wenger, 1999);

3. environments, resources and activities that taking into consideration this organizational background would enable professional learners to self-direct their own learning interests, opening to opportunities to reflect and have these efforts recognized by a system (Dircking Homfeld, Jones, \& Lindstrom, 2005; Pataraia, Margaryan, Falconer, \& Littlejohn, 2013); 
4. showcase areas, namely, the possibility of showing the concrete results of professional learning: if it is connected to concrete processes to innovate practices, it should lead to new products, reflections, ideas. In the case of teaching, this is clearly connected to the models of action research, where design-based experiments are conducted in order to support experiential learning on specific teaching techniques.

\section{Discussion: the missed dialogue between Digital Scholarship and Faculty Development}

The brief exploration of the literature on digital scholarship and faculty development conducted hitherto should establish the conditions to discuss the research question are faculty development strategies hindered by the lack of a cohesive view in the research on digital scholarship? Indeed, our exploration of the literature disclose two order of problems relating how the advancements in digital scholarship are (or could) inform professional development research and practices needed to become a digital scholar.

The first problem is that the research on faculty development to achieve digital skills for the academic profession have been mainly focused on online teaching (McKee, Johnson, Ritchie, \& Tew, 2013). In spite of the importance of open education and elearning for the movement of educational technologies, digital scholarship is a far more complex practice, as the same authors of the mentioned perspective have pointed out. Just as example, on the basis of the revisited DIAT model of Boyer, Weller (2011) pointed out the importance of new forms of academic communication through blogging and social networks between research and teaching as two areas of practice with blurring boarders. Furthermore, the online teaching issue is almost inexistent in the first perspective on digital scholarship (information sciences), which focus is mainly research and the scientific communication to the scientific community or the wider public, as we showed earlier. Moreover, the overwhelming information about faculty development on the area of online teaching seems to be in contradiction with the fact that doing research is allegedly the primary endeavour for scholars and the main element for careers' advancement. Seemingly, the lack of attention of faculty development to digital research skills or discovery in Boyer's terms could be explained by a rather pragmatic approach of professional learning where the scholars achieve the specific professional skills through highly informal activities. In fact, it is the same expertise on a research domain that guides the self-recognition of skills' gap and the associated learning activities and resources required to fulfil the professional learning needs. The fact mentioned above are clearly underlining a clear disconnection between faculty development and digital scholarship.

The second problem goes in the opposite direction, from the research on digital scholarship to the issue of faculty development. It regards the fact that the research on the former topic has not considered yet the problem of designing, deploying and evaluating professional development towards the skills and processes required to become (act and being) a digital scholar, a focus that would bridge research on the two issues under analysis here.

As Raffaghelli, Cucchiara, Manganello, and Persico (2015) pointed out, a close look to studies analysing digital scholarship shows that most of them are based on observational approaches that explore and observe existing practices, reporting objective data or phenomenological or narrative accounts on what it is. Moreover, most 
studies build on more or less acknowledged values on scholarship (towards more open and digitalized practices) but they just show a current picture and eventually point out the criticalities and conflicts of trying to be a digital scholar in the middle of traditional systems. With no interventionist studies, both experimental or design-based research that take into consideration an initial framework, device or model to be tested, it is clear that the directions for practice are uncertain. In this vein, the same authors explored a more evident question, namely "how many studies on digital scholarship considered professional development on the topic?” The findings showed a situation where very few studies considered specific instructions for professional development (subject areas, the stage professional development (9\% of studies), general approaches to adopt digital tools for research and teaching (20\%) and design and testing of a model of professional development for Digital Scholarship not considered at all (71\%) (Raffaghelli et al., p.14).

More recently, the studies have started to make proposals relating to frameworks of practice and eventually competence, like academic microblogging (Heap \& Minocha, 2012), reputation building (Nicholas \& Herman, 2016) or the adoption of open datasets as open educational resources (Atenas, Havemann, \& Priego, 2015). A first comprehensive effort to build a theoretical and operational framework of competences for young researchers has been offered by Ranieri (2014). However, her attempt was based on an initial reflection on initial training required to do research. Therefore, a comprehensive framework that analyses scholarship as lifelong learning endeavour and as professional area integrated by diversified activities beyond teaching or research and hence based on shared values and a broad vision of what being a digital scholar and practicing digital scholarship is, is still missed.

Having said this, we could now attempt to answer the second subsidiary question, how the fragmentary vision of digital scholarship influences incomplete practices in faculty development?, drafting three scenarios of faculty development for digital scholarship. In order to build the scenarios, we will inspect every perspective on digital scholarship through the four requirements for effective faculty development: the framework of competences and scenarios of expertise; the institutional strategies and policies; the environments, resources and activities and the showcase areas. We will inform every scenario with the existing (but highly fragmentary and incomplete) literature relating professional development for the perspective digital scholarship under analysis.

\section{Three scenarios of faculty development for digital scholarship}

For the first perspective (Information Sciences), the focus of digital scholarship is scientific communication, enhanced by digital technologies, and more recently, the open research practices, participatory science and new modes of disseminating the scientific work. The main theoretical model of reference to consider professionalism regards the cycle of scientific communication (Borgman, 2007) and the competent management of the workflow thereby proposed. If we take into consideration the European context, only in the recent years several proposals for training researchers to adopt more actively Open Access have increased. Several European documents address the need of researchers' training, that is, opportunities for formal learning on issues like Open Access, opening up science, open peer-review and open data management and publication. As a matter of fact, a complete picture of what was conceived as digital 
science was presented within the concept paper digital science at Horizon 2020 by the DG Connect (European Commission, 2013), where a vision on digital science, a conceptual framework and a number of operational dimensions guiding also researchers' training were considered. Moreover, the communication of the European Commission (COM 2016178 final) on the new European cyberinfrastructures supporting science highlights that necessary action to implement the European Cloud Initiative is to raise awareness and change incentive structures for academics, industry and public services to share their data, and improve data management training, literacy and data stewardship skills (p.6). More recently the High Level Expert Group on European Science Cloud was created, and in the first report produced by this group produced the recommendation of training is made repeatedly requested as part of a strategy to promote more researchers' engagement and awareness on Open Science (Ayris et al., 2016). Moreover, in March 2016 at the Futurium space of the DG Connect for public consultation and debate, a working document on Open Scholarship for the adoption on eInfrastructures introduced a synthesis on the European Commission's endeavour on the matter, claiming for actions to cooperate with the New Skills and Professions group to design an action plan for training a new generation of scholars and shaping model policies for career development in Open Scholarship (Matt, 2016).

Finally, in October 2015 the Horizon 2020 workprogramme on Science with and for Society launched a call to fund projects aiming at training scholars for Open Science (European Commission Decision, 2016), closed by October 2016. A new generation of training activities will be promoted through this call, and a framework of reference will probably developed.

However, the models adopted have their focus on promoting specific competences rather than an overarching discussion of what it takes to be a digital scholar. In fact, a framework of competences would be based on the cycle of information science and the competent adoption open science instruments (open access, open data, open innovation). With regard to the institutional strategies and policies, in this first scenario the strategies are to be focused on the promotion of Open Access and Open Science as new frontiers of scientific communication, hence adopting policies to give value to open science. The environments, resources and activities required to this endeavour would be (as it is already) a mix of blended strategies promoted by university libraries and associations promoting open science; the initiatives would probably emphasize content (e.g. regulations for Open Access and Open Sciences, differences between institutional repositories and academic social networks, bibliometrics and altmetrics for the evaluation of research quality). Finally, for the showcase areas we would expect to see the products of practices relating open access scientific communication, public and participatory science, open peer evaluation, etc.

As for the second scenario, based on the perspective of Digital Humanities, the same evolution of the disciplinary debate on what being a humanist in the digital age means, has led to the creation of research centres for Digital Humanities (Romero-Frías \& Del-Barrio-García, 2014). The framework of competences and scenarios of professional expertise are focused on activities of exploring the specific methods of digital humanities and the methodological debate (particularly ontological) on the nature of digitalized cultural heritage (Unsworth, 2013). The institutional policies are aimed at opening areas or centres to promote the development of digital humanities both from the technical 
(software, tools, labs), but also to cultivate the critical perspective on the methodological evolution of humanities at the cross-over with new computational methods (Klein, 2015). Therefore, the training activities would (and actually do) emphasize the adoption of instruments for digitalize or to manipulate digitalized cultural heritage. More recently, there is also an effort to build international communities sharing digital objects and discussing the methodological perspectives to their creation and analysis (Borgman, 2015).

The third scenario is based on the advances of research in the field of educational technologies and professional learning in digital and networked spaces. It mainly refers to the revisited theoretical DIAT model of Boyer under the light of digital contexts and instruments; in this model, scholarship is divided into four dimensions of activity. In spite of this reference, very few frameworks of competence to become and to be an expert digital scholar have been elaborated. Some of them could be too specifically related to a tool (i.e. academic blogging, by Heap \& Minocha, 2012) or to a dimension of scholarship (i.e., discovery in the earlier stages of researchers' professional development, by Ranieri, 2014). For this perspective, in fact, the training focus could be scholars' professional learning and identity change while dealing with digital, networked and open contexts of academic practice (Goodfellow, 2014; Pearce et al., 2010). Institutional strategies in this perspective should enable researchers to adopt informal, networked communication of an intertwined perspective of research and teaching in the making. Moreover, open online teaching and digital contents for learning should be considered in the evaluation of activities for career advancement. A debate on this topic has been clearly headed by the case of MOOCs (Massive Open Online Courses) (Daniel, Cano, \& Gisbert, 2015). As for the environments, resources and training activities, these would take the form of professional communities to reflect on the new practices and identity of the digital scholar. In line with this hypothesis, a recent open

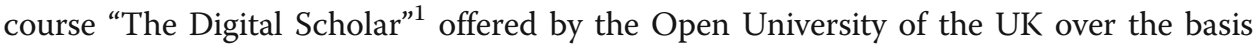
of Weller's work discussed the new frontiers of practice for digital scholarship taking into consideration teaching and learning as part of digital, open and networked professional practices; in this course an internal simulation of professional networks through the "OpenStudio" tool showed participants how they were engaged and which were their contributions semantically organized. In fact, the showcase areas would probably aim at showing networks of digital scholarship, sharing stories on new practices, as narratives of what it takes to be a digital scholar is.

The Table 1 synthesize the above hypothesized scenarios of faculty development for digital scholarship taking into consideration the three perspectives that contribute to the development of the topic.

\section{Conclusions}

In this article the challenge was to understand how the current situation of the research digital scholarship influences the practices of faculty development. Moreover, the aim was to show to which extent the lack of a cohesive conception of what it is to practice digital scholarship and to be a digital scholar hinders faculty development's strategies.

A careful look at literature highlighted the elusiveness of the concept of digital scholarship, with several disciplines contributing to the topic with diversified (and scarcely connected) conceptual frameworks and approaches to research. To this regard we analysed the literature and considered studies that already pointed out the problem 
Table 1 Scenarios of faculty development for digital scholarship

\begin{tabular}{|c|c|c|c|}
\hline \multirow{2}{*}{$\begin{array}{l}\text { Dimensions of faculty } \\
\text { development }\end{array}$} & \multicolumn{3}{|c|}{ Disciplines contributing to the perspectives on digital scholarship } \\
\hline & Information sciences & Digital humanities & Educational technologies \\
\hline $\begin{array}{l}\text { Framework of } \\
\text { competences and } \\
\text { scenarios of expertise } \\
\text { focused on... }\end{array}$ & $\begin{array}{l}\text {... The cycle of scientific } \\
\text { communication, } \\
\text { encompassing open } \\
\text { research practices, } \\
\text { participatory science and } \\
\text { new modes of disseminating } \\
\text { the scientific work. }\end{array}$ & $\begin{array}{l}\text {... Specific methods of } \\
\text { digital humanities and the } \\
\text { methodological debate } \\
\text { (particularly ontological) on } \\
\text { the nature of digitalized } \\
\text { cultural heritage }\end{array}$ & $\begin{array}{l}\text {... Building a professional } \\
\text { identity as digital scholars } \\
\text { while dealing with digital, } \\
\text { networked and open } \\
\text { contexts of academic } \\
\text { practice (including research } \\
\text { and teaching). }\end{array}$ \\
\hline $\begin{array}{l}\text { Institutional strategies } \\
\text { and policies for... }\end{array}$ & $\begin{array}{l}\text {... Promoting Open Access } \\
\text { and Open Science as new } \\
\text { frontiers of scientific } \\
\text { communication. }\end{array}$ & $\begin{array}{l}\text {... Opening areas or centres } \\
\text { to promote the development } \\
\text { of digital humanities both } \\
\text { from the technical (software, } \\
\text { tools, labs) and the } \\
\text { methodological point } \\
\text { of view. }\end{array}$ & $\begin{array}{l}\text {... Enabling researchers to } \\
\text { adopt informal, networked } \\
\text { communication of an } \\
\text { intertwined perspective of } \\
\text { research and teaching. }\end{array}$ \\
\hline $\begin{array}{l}\text { Environments, } \\
\text { resources and activities } \\
\text { as... }\end{array}$ & $\begin{array}{l}\text {... A mix of blended } \\
\text { (online and face-to-face), } \\
\text { active and flexible } \\
\text { approaches with emphasis } \\
\text { on content like: Regulations } \\
\text { for Open Access and Open } \\
\text { Sciences, differences } \\
\text { between institutional } \\
\text { repositories and academic } \\
\text { social networks, bibliometrics } \\
\text { and altmetrics for the } \\
\text { evaluation of research } \\
\text { quality), etc. }\end{array}$ & $\begin{array}{l}\text {... A mix of blended active } \\
\text { and flexible approaches } \\
\text { with emphasis on the } \\
\text { adoption of instruments for } \\
\text { digitalize or to manipulate } \\
\text { digitalized cultural heritage, } \\
\text { as well as communities for } \\
\text { the methodological debate. }\end{array}$ & $\begin{array}{l}\text {... A mix of blended and } \\
\text { flexible approaches with } \\
\text { emphasis on building } \\
\text { professional communities } \\
\text { to reflect on the new } \\
\text { practices and identity of } \\
\text { the digital scholar. }\end{array}$ \\
\hline Showcase areas for... & $\begin{array}{l}\text {... Showing the products } \\
\text { of practices (open access } \\
\text { scientific communication). }\end{array}$ & $\begin{array}{l}\text {... Showing the products } \\
\text { of practices (digitalized } \\
\text { cultural heritage). }\end{array}$ & $\begin{array}{l}\text {... Sharing stories on new } \\
\text { practices, as narratives of } \\
\text { what it takes to be a } \\
\text { digital scholar. }\end{array}$ \\
\hline
\end{tabular}

of fragmentation in the field of digital scholarship. The next step was to understand how the weaknesses of research in the first area impact on faculty development as applied area of research. To this endeavour, we analysed the literature on faculty development, in an attempt to understand which the dimensions of effectiveness and quality are. On these basis, we acknowledge four main dimensions for effective professional development, namely, a framework of competences and scenarios of expertise with middle stages of development (from novice to expert), that are closely connected not only with the developmental processes within the organization but also the society; institutional strategies and policies connected to developmental processes within the organization, that in time recognize the existence of embedded professional communities with their values, identity and practices; environments, resources and activities that taking into consideration this organizational background enable professional learners to self-direct own learning interests, opening to opportunities to reflect and have these efforts recognized by a system; showcase areas where is possible for the professional learner to present the concrete results of innovative practices and ideas cultivated along the process of professional learning.

At this point, the assumption that a lack of cohesive views of what it is a digital scholar, as professional profile and connected practices and values, would hinder clear action taking for professional development was clearly supported by the literature. Moving forward to get further evidence in this direction, we introduced three scenarios of faculty development for digital scholarship. The three scenarios were based on the 
three diverse perspectives in this last area. We could observe that a sectorial perspective on the scholar's professional activity would encompass a limited vision on the type of contents, skills and products of training, against a broader debate of what being a digital scholar is. In fact, the first and second scenario were highly specific when coming to tools and institutional strategies, but they missed an overall picture on the professional identity forged through participation within open science and digital humanities. Instead, the third scenario was less punctual in connecting the reflections of digital scholarship with technical tools and infrastructures, giving excessive value to social media and networks where in other cases (information sciences) their adoption has raised polemics. The three scenarios let us envisage the goals of professional development for digital scholarship as improving innovation in the use of digital tools, becoming networked professionals and adopting a consistent code of conduct relating opening up research and education. The way they focus contents and activities as well as the specific competences envisaged for the professional profile are diversified and even conflicting in some cases. Moreover, there was no agreement on the overall profile of a digital scholar, with little attention to teaching in the first and second perspective against the importance given to this activity in the third.

To achieve a broader picture of digital scholarship, the existing and frequently used framework Boyer's DIAT model relating the academic profession, should become more dynamic (considering levels of professional learning spanning from the novice to the expert) and better integrate with research on the definition of a framework considering researchers' workflow and the types of production along the scientific information life cycle for Open Science, as it is the main focus of the information science; as well as the research on scholars' reputation and identity. Finally, a connection between the methods and approaches to online teaching analysed by the research on faculty development could be the base to discuss methodological approaches for the overall development strategies for digital scholarship. It seems not the case to replace models like Boyer's one, revisited in several studies on open and social scholarship like those carried out by Veletsianos $(2012,2014,2016)$, but to integrate and enrich it to make it become a complete taxonomy or even a pedagogical ontology encompassing contents, activities, learning goals and encompassed outcomes, and tools for evaluation and recognition of competences.

The remarks for future research that ensue are connected to three main concerns arising from the need of creating a more cohesive view of digital scholarship bridging faculty development. The three issues are: interdisciplining research in digital scholarship, adopting new interventionist methodological approaches and building a more comprehensive framework for professional development.

As for the interdisciplinary approach to research in digital scholarship, the immediate advantage would be the cross-fertilization of models on scholarship in the new digital open and networked contexts of knowledge. In fact, interdisciplinarity emerged as the approach leading the effort to understand how consolidated disciplines could collaborate and to explore the effectiveness of this collaboration (Klein, 1996; Nissani, 1997) Transnational, European and national research agencies are starting to consider and to support interdisciplinary research since it has been connected to innovation and responsiveness to social problems (Moran, 2010). Despite the advantages, researchers still thrive to engage in interdisciplinary projects since career advancement and research projects' 
evaluation are based on traditional disciplinary perspectives (Leahey, Beckman, \& Stanko, 2015; Rons, 2011); this is a fact that we could appreciate in our initial description of the three disciplinary traditions that study digital scholarship. The fact is maybe due to the way technology has evolved: from one side, the technological development of tools, environments and interfaces requires the participation of math, computer science, engineering, etc.; however, the technological uptake is a social and cultural phenomenon that requires the engagement of sociology, anthropology, psychology and educational sciences. The relationships between these several worlds raise not only specific methodological issues, but also epistemological questions like the need of overcoming technological determinism and the socio-material perspective (Fenwick, 2010). As a matter of fact, in the specific case of educational technologies, an hybrid area by definition, Conole, Scanlon, Mundin, \& Farrow, 2010 p. 10) highlighted that ...It is evident that interdisciplinarity is a core feature of TEL (technology-enhanced learning) research. However, for these same authors, interdisciplinarity entails concrete difficulties hindering the advancement of the TEL research: ... multiplicity also brings challenges, such as a lack of a shared coherent discourse, tensions and power struggles between the different subject domains and a lack of perceived rigour and credibility (op.cit, p.10).

We might expect that digital scholarship, as topic at the crossover of information science, computer science, educational technologies, sociological and anthropological studies will introduce similar challenges that need to be explored to put the basis of solid interdisciplinary collaboration, and the need to elaborate concrete bases for faculty development on digital scholarship could support this endeavour.

The issue of methodological approaches within the research on digital scholarship is intertwined with this last assumption. As we observed here, most studies are based on observational research. To understand faculty development on digital scholarship, there is need instead of developing frameworks to be tested, going beyond descriptions/ observations to take actions and analyse impacts, as it would be the case of design-based research studies on researchers' training on digital scholarship (Raffaghelli, Valla, Cucchiara, Giglio, \& Persico, 2014). In fact, the topic of the professional development of researchers' skills to become digital scholars is frequently missed in the research on digital scholarship, showing that the design, development and test of models and strategies is still far. Last, but not least, the vision of expertise and its connected values put the bases to recognize professional learning and career advancement. To this regard, the research should also consider that organizational change (i.e., introducing open science and networked scholarship) may be based on professional development. However, it is necessary to go beyond traditional, on-site training, towards the creation of flexible approaches, with professional learning environments that adopt advanced technologies like recommendation systems endowing participants to develop professional skills (Manganello, Falsetti, Spalazzi, \& Leo, 2013). These different approaches should be further tested in order to analyse their effectiveness.

To conclude, we would like to consider the sharp synthesis made by Esposito (2013) on the current state of digital scholarship. As she pointed out, scholars are "traditionally 'digital', moderately 'networked' and occasionally 'open'" (2013, n.p.). Therefore, the combined research on faculty development for digital scholarship, on the basis of a more cohesive approach to this last, could confirm criticalities and opportunities to design and test pedagogical approaches for the frontiers of digital scholarship. 


\section{Endnote}

${ }^{1}$ http://www.open.edu/openlearn/education/the-digital-scholar/content-section-overview.

\section{Competing interests}

The author declares that she has no competing interests.

\section{Publisher's Note}

Springer Nature remains neutral with regard to jurisdictional claims in published maps and institutional affiliations.

Received: 17 February 2017 Accepted: 11 May 2017

Published online: 01 August 2017

\section{References}

Amundsen, C., \& Wilson, M. (2012). Are We Asking the Right Questions?: A Conceptual Review of the Educational Development Literature in Higher Education. Review of Educational Research, 82(1), 90-126. http://doi.org/10.3102/ 0034654312438409. Accessed 16 May 2017

Andersen, D. L. (2003). In D. L. Andersen (Ed.), Digital Scholarship in the Tenure, Promotion, and Review Process. London \& New York: M.E. Sharpe

Andersen, D., \& Trinkle, D. (2004). Valuing digital scholarship in the tenure, promotion, and review process - A survey of academic historians. In D. Andersen (Ed.), Digital Scholarship in the Tenure, Promotion and Review Process (pp. 61-77). New York: M.E. Sharpe.

Atenas, J., Havemann, L., \& Priego, E. (2015). Open Data as Open Educational Resources: Towards Transversal Skills and Global Citizenship. Open Praxis, 7(4), 377-389. http://doi.org/10.5944/openpraxis.7.4.233. Accessed 16 May 2017

Ayers, E. (2004). Doing Scholarship on the Web: Ten Years of Triumphs — and a Disappointment. Journal of Scholarly Publishing, 35(3), 143-147. http://doi.org/10.3138/jsp.35.3.143. Accessed 16 May 2017

Ayris, P., Berthou, J.-Y., Bruce, R., Lindstaedt, S., Monreale, A., Mons, B., .. Tochtermann, Klaus Wilkinson, R. (2016). Realising the European Open Science Cloud. First report and recommendations of the Commission High Level Expert Group on the European Open Science Cloud. Luxembourg.

Bahar-Ozvaris, S., Aslan, D., Sahin-Hodoglugil, N., \& Sayek, I. (2004). A Faculty Development Program Evaluation: From Needs Assessment to Long-Term Effects, of the Teaching Skills Improvement Program. Teaching and Learning in Medicine, 16(4), 368-375. http://doi.org/10.1207/s15328015tlm1604_11. Accessed 16 May 2017

Bentkowska-Kafel, A. (2013). "I bought a piece of Roman furniture on the Internet. It's quite good but low on polygons. "-Digital Visualization of Cultural Heritage and its Scholarly Value in Art History. Visual Resources, 29(1-2), 38-46. http://doi.org/10.1080/01973762.2012.761117. Accessed 16 May 2017

Borgman, C. L. (2007). Scholarship in the Digital Age. Cambridge: MIT Press.

Borgman, C. L. (2008). Supporting the"Scholarship" in E-Scholarship. EDUCAUSE Review, 43(6), 32-33.

Borgman, C. L. (2015). Big Data, Little Data, No data: Scholarship in the Networked World. Cambridge: MIT Press.

Boud, D. (1999). Situating academic development in professional work: Using peer learning. International Journal for Academic Development, 4(1), 3-10. http://doi.org/10.1080/1360144990040102. Accessed 16 May 2017

Boyer, E. L. (1990). Scholarship reconsidered: priorities of the professoriate (Vol. 1997). San Francisco: Carnegie Foundation.

Boyer, E. L., Moser, D., Ream, T. C., \& Braxton, J. M. (2015). Scholarship Reconsidered: Priorities of the Professoriate. San Francisco: Wiley\&Sons.

Braxton, J. M., Luckey, W., \& Helland, P. (2002). Institutionalizing a broader view of scholarship through Boyer's four domains. Hoboken: Wiley- Jossey Bass.

Centra, J. A. (1978). Faculty Development in Higher Education. Teachers College Record, 80(1), 188-201.

Cole, K. A., Barker, L. R., Kolodner, K., Williamson, P., Wright, S. M., \& Kern, D. E. (2004). Faculty development in teaching skills: an intensive longitudinal model. Academic Medicine: Journal of the Association of American Medical Colleges, 79(5), 469-80

Conole, G., Scanlon, E., Mundin, P., \& Farrow, R. (2010). Interdisciplinary Research. Findings from the Technology Enhanced Learning Research Programme. Milton Keynes. Retrieved from http://www.tlrp.org/docs/TELInterdisciplinarity.pdf. Accessed 16 May 2017

Costa, C. (2013). The habitus of digital scholars. Research in Learning Technology, 21. http://doi.org/10.3402/ rlt.v21i0.21274. Accessed 16 May 2017

Costa, C. (2014). Outcasts on the inside: academics reinventing themselves online. International Journal of Lifelong Education, 34(2), 194-210. http://doi.org/10.1080/02601370.2014.985752. Accessed 16 May 2017

Cox, M. D. (2004). Introduction to faculty learning communities. New Directions for Teaching and Learning, 2004(97), 5-23. http://doi.org/10.1002/tl.129. Accessed 16 May 2017

Cox, J. (2016). Communicating new library roles to enable digital scholarship: A review article. New Review of Academic Librarianship, 22(2/3), 132-147. http://doi.org/10.1080/13614533.2016.1181665. Accessed 16 May 2017

Daniel, S. J., Cano, E. V., \& Gisbert, M. (2015). The Future of MOOCs: Adaptive Learning or Business Model? RUSC. Universities and Knowledge Society Journal, 12, 1.

De Solla Price, D. J. (1963). Little Science, Big Science. New York: Columbia University Press.

Den Besten, M., David, P., \& Schroeder, R. (2010). Research in e-Science and Open Access to Data Information. In J. Husinger, L. Klastrup, \& J. Allen (Eds.), International Handbook of Internet Research (pp. 65-96). London \& New York http://doi.org/10.1007/978-1-4020-9789-8. Accessed 16 May 2017

Dircking Homfeld, L., Jones, C., \& Lindstrom, B. (2005). In L. Dircking Homfeld, C. Jones, \& B. Lindstrom (Eds.), Analysing Networked Learning Practices in Higher Education and Continuing Professional Development (1st ed.). Rotterdam/ Boston/Taipei: Sense Publishers. 
Esposito, A. (2013, January 9). Neither digital or open. Just researchers: Views on digital/open scholarship practices in an Italian university. First Monday, S.I. http://dx.doi.org/10.5210/fm.v18i1.3881. Accessed 16 May 2017

Esposito, A. (Ed.). (2017). Research 2.0 and the Impact of Digital Technologies on Scholarly Inquiry. Hershey: IGI Global. http://doi.org/10.4018/978-1-5225-0830-4. Accessed 16 May 2017

Esposito, A., Sangrà, A., \& Maina, M. (2013). Chronotopes in learner-generated contexts. A reflection about the interconnectedness of temporal and spatial dimensions to provide a framework for the exploration of hybrid learning ecologies of doctoral e-researchers. elearn Center Research Paper Series. Retrieved from http://journals.uoc. edu/index.php/elcrps/article/view/1868/n6-esposito-ePub. Accessed 16 May 2017

European Commission Decision. (2016). Horizon 2020 Work Programme 2016-2017. 16. Science with and for Society, 2017(July 2016), 1-72. Retrieved from http://ec.europa.eu/research/participants/data/ref/h2020/wp/2016_2017/ main/h2020-wp1617-swfs_en.pdf. Accessed 16 May 2017

European Commission. (2013). Digital science in Horizon 2020. Working document, European Commission, Brussels. Retrieved from ec.europa.eu/information_society/newsroom/cf/dae/document.cfm?doc_id = 2124 .

European Commission. (2016). COM(2016)178. European Cloud Iniative. Retrieved from https://ec.europa.eu/digital-singlemarket/en/news/communication-european-cloud-initiative-building-competitive-data-and-knowledge-economy-europe

Evans, L. (2008). Professionalism, professionality and the development of education professionals. British Journal of Educational Studies, 56(1), 20-38

Fecher, B., \& Friesike, S. (2013). Open Science: One Term, Five Schools of Thought. SSRN Electronic Journal, RatSWD_WP_. http://doi.org/10.2139/ssrn.2272036. Accessed 16 May 2017

Fenwick, T. (2010). Re-thinking the "thing": Sociomaterial approaches to understanding and researching learning in work. Journal of Workplace Learning, 22(1/2), 104-116. http://doi.org/10.1108/13665621011012898. Accessed 16 May 2017

Flanders, J. (2013). The productive unease of 21st-century digital scholarship. In Defining Digital Humanities: A Reader (pp. 205-218). Ashgate Publishing Ltd.

Gardiner, E., \& Musto, R. G. (2015). The Digital Humanities A Primer for Students and Scholars. Harvard: Harvard University Press.

Garnett, F., \& Ecclesfield, N. (2012). Towards a framework for co-creating Open Scholarship. Research in Learning Technology, 19, http://doi.org/10.3402/rlt.v19i3.7795. Accessed 16 May 2017

Goodfellow, R. (2014). Scholarly, digital, open: an impossible triangle? Research in Learning Technology, 21. http://doi.org/10. 3402/rlt.v21.21366. Accessed 16 May 2017

Goodfellow, R. (2013). The literacies of "digital scholarship" - truth and use values. In R. Goodfellow \& M. Lea (Eds.), Literacy in the Digital University: Critical Perspectives on learning, scholarship, and technology (p. 218). London: Routledge.

Goodfellow, R., \& Lea, M. (2013). Literacy in the Digital University: Critical Perspectives on learning, scholarship, and technology. London: Routledge.

Gorard, S. (2004). Combining Methods in Educational and Social Research. Maidenhead: OpenUniversity Press-McGraw Hill Education.

Gorard, S., \& Cook, T. (2007). Where does good evidence come from? International Journal of Research \& Method in Education, 30(3), 307-323. http://doi.org/10.1080/17437270701614790. Accessed 16 May 2017

Grand, A., Wilkinson, C., Bultitude, K., \& Winfield, A. F. T. (2012). Open Science: A New “Trust Technology"? Science Communication, 34(5), 679-689. http://doi.org/10.1177/1075547012443021. Accessed 16 May 2017

Greenhow, C., \& Gleason, B. (2014). Social scholarship: Reconsidering scholarly practices in the age of social media. British Journal of Educational Technology, 45(3), 392-402. http://doi.org/10.1111/bjet.12150. Accessed 16 May 2017

Grover, K. S. Walters. S. R. C. (2016). Exploring Faculty Preferences for Mode of Delivery for Professional Development Initiatives. Online Journal of Distance Learning Administration, 19(1).

Guskey, T. R., \& Yoon, K. S. (2009). What Works in Professional Development? Phi Delta Kappan, 19(7), 495-500. http://doi.org/10.2307/20446159. Accessed 16 May 2017

Hall, G. (2015). Should This Be the Last Thing You Read on Academia.edu? Radical Open Access conference. Retrieved from https://www.academia.edu/16959788/Should_This_Be_the_Last_Thing_You_Read_on_Academia.edu. Accessed 16 May 2017

Heap, T., \& Minocha, S. (2012). An empirically grounded framework to guide blogging for digital scholarship. Research in Learning Technology, 20 (Supp). pp. 176-188. https://doi.org/10.3402/rlt.v20i0.19195. Accessed 16 May 2017

Hendriks, M., Luyten, H., Scheerens, J., Sleegers, P., \& Steen, R. (2010). Teachers' Professional Development. Europe in the international Comparison. (Scheerens, Ed.). Louxembourg: Office for Official Publications of the European Union. http://doi.org/10.2766/63494. Accessed 16 May 2017

Hernon, P. (1994). Information life cycle: Its place in the management of U.S. government information resources Government Information Quarterly, 11(2), 143-170. http://doi.org/10.1016/0740-624X(94)90002-7. Accessed 16 May 2017

Hildebrandt, K., \& Couros, A. (2016). Digital selves, digital scholars: Theorising academic identity in online spaces. Journal of Applied Social Theory, 1, 2016.

Holliman, R. (2010). From analogue to digital scholarship: Implications for science communication researchers. Journal of Science Communication, 9(3), C05.

Jamali, H. R., Nicholas, D., Watkinson, A., Herman, E., Tenopir, C., Levine, K., Nichols, F. (2014). How scholars implement trust in their reading, citing and publishing activities: Geographical differences. Library \& Information Science Research, 36(3-4), 192-202. http://doi.org/10.1016/j.lisr.2014.08.002. Accessed 16 May 2017

Jamali, H. R., Nicholas, D., \& Herman, E. (2016). Scholarly reputation in the digital age and the role of emerging platforms and mechanisms. Research Evaluation, 25(1), 37-49. http://doi.org/10.1093/reseval/rvv032. Accessed 16 May 2017

Kaltenbrunner, W. (2015). Infrastructural Inversion as a Generative Resource in Digital Scholarship. Science as Culture 24(1), 1-23. http://dx.doi.org/10.1080/09505431.2014.917621. Accessed 16 May 2017

Kjellberg, S. (2014). Researchers' blogging practices in two epistemic cultures the scholarly blog as a situated genre. Human IT, 12,3.

Klein, J. T. (1996). Crossing Boundaries: Knowledge, Disciplinarities, and Interdisciplinarities. London: University of Virginia Press. Klein, J. T. (2015). Interdisciplining Digital Humanities: Boundany Work in an Emerging Field. Ann Arbor: University of Michigan Press.

Leahey, E., Beckman, C., \& Stanko, T. (2015). Prominent but Less Productive: The Impact of Interdisciplinarity on Scientists' Research (Digital Libraries). Retrieved from http://arxiv.org/abs/1510.06802. Accessed 16 May 2017 
Manca, S., \& Ranieri, M. (2016a). "Yes for sharing, no for teaching!": Social Media in academic practices. The Internet and Higher Education, 29, 63-74. http://doi.org/10.1016/j.iheduc.2015.12.004. Accessed 16 May 2017

Manca, S., \& Ranieri, M. (2017). Exploring Digital Scholarship: A study on Use of Social Media for Scholarly communication among Italian Academics. In Research 2.0 and the Impact of Digital Technologies on Scholarly Inquiry (Ed: Antonella Esposito) Vol. 33, pp. 117-142. Hershey: IGl Global. http://doi.org/10.4018/978-1-5225-0830-4.ch007. Accessed 16 May 2017

Manganello, F., Falsetti, C., Spalazzi, L., \& Leo, T. (2013). PKS: An ontology-based Learning Construct for Lifelong Learners. Educational Technology \& Society, 16(1), 104-117.

Matt, S. (2016). e-Infrastructures to facilitate Open Scholarship. Retrieved from https://ec.europa.eu/futurium/en/content/ e-infrastructures-facilitate-open-scholarship. Accessed 16 May 2017

McKee, C. W., Johnson, M., Ritchie, W. F., \& Tew, W. M. (2013). Professional Development of the Faculty: Past and Present. New Directions for Teaching and Learning, 2013(133), 15-20. http://doi.org/10.1002/tl.20042. Accessed 16 May 2017

Merton, R. K., \& Garfield, E. (1986). Little Science Big Science - Foreword. Retrieved from http://www.garfield.library.upenn. edu/lilscibi.html. Accessed 16 May 2017

Meyer, K. A. (2014). An Analysis of the Cost and Cost-Effectiveness of Faculty Development for Online Teaching. Journal of Asynchronous Learning Networks, 17(4), 93-113.

Moran, J. (2010). Interdisciplinarity. London: Routledge.

NASCIMBENI, Fabio; BURGOS, Daniel. In Search for the Open Educator: Proposal of a Definition and a Framework to Increase Openness Adoption Among University Educators. The International Review of Research in Open and Distributed Learning, 17 (6). ISSN 1492-3831. doi:10.19173/irrodl.v17i6.2736. Accessed 16 May 2017

Nicholas, D., \& Herman, E. (2016). Scholarly activities and reputation in the digital age: A conceptual framework. Retrieved from http://ciber-research.eu/download/20161116-Reputation_WP1_Scholarly_Activities.pdf. Accessed 16 May 2017

Nissani, M. (1997). Ten Cheers for Interdisciplinarity: The Case for Interdisciplinary Knowledge and Research. The Social Science Journal, 34(2), 201-216.

Oliveira, N. R., Morgado, L., Alvesson, M., Ashcraft, K. L., Thomas, R., Amichai-Hamburger, Y...., Warburton, S. (2017). Digital Identity of Researchers 2.0. In Research 2.0 and the Impact of Digital Technologies on Scholarly Inquiry (Vol. 15, pp. 270-289). IGI Global. http://doi.org/10.4018/978-1-5225-0830-4.ch014. Accessed 16 May 2017

Palmer, C. L., \& Cragin, M. H. (2008). Scholarship and disciplinary practices. Annual Review of Information Science and Technology, 42(1), 163-212. http://doi.org/10.1002/aris.144.v42:1. Accessed 16 May 2017

Pataraia, N., Margaryan, A., Falconer, I., \& Littlejohn, A. (2013). How and what do academics learn through their personal networks. Journal of Further and Higher Education, 39(3), 336-357. http://doi.org/10.1080/0309877X.2013.831041. Accessed 16 May 2017

Pearce, N., Weller, M., Scanlon, E., \& Kinsley, S. (2010). Digital Scholarship Considered: How New Technologies Could Transform Academic Work. In Education. Retrieved from http://ineducation.ca/ineducation/article/view/44/508

Petticrew, M., \& Roberts, H. (2006). Systematic Reviews in the Social Sciences: A Practical Guide. Oxford: Blackwell Publishing Ltd.

Pontika, N., Knoth, P., Cancellieri, M., \& Pearce, S. (2015). Fostering open science to research using a taxonomy and an eLearning portal. In Proceedings of the 15th International Conference on Knowledge Technologies and Data-driven Business - i-KNOW'15 (pp. 1-8). New York, New York, USA: ACM Press. http://doi.org/10.1145/2809563.2809571. Accessed 16 May 2017

Quan-Haase, A., Suarez, J. L., \& Brown, D. M. (2014). Collaborating, Connecting, and Clustering in the Humanities: A Case Study of Networked Scholarship in an Interdisciplinary, Dispersed Team. American Behavioral Scientist, 59(5), 565-581. http://doi.org/10.1177/0002764214556806. Accessed 16 May 2017

Quigley, D. S., Neely, E., Parkolap, A., \& Groom, G. (2013). Scholarship and Digital Publications: Where Research Meets Innovative Technology. Visual Resources, 29(1-2), 97-106. http//doi.org/10.1080/01973762.2013.761122. Accessed 16 May 2017

Raffaghelli, J. E., Cucchiara, S., Manganello, F., \& Persico, D. (2015). Digital Scholarship: a Systematic Review of Literature. Report, Institute of Educational Technologies. Genoa: Italian National Research Council.

Raffaghelli, J. E., Cucchiara, S., Manganello, F., \& Persico, D. (2016). Different views on Digital Scholarship: separate worlds or cohesive research field? Research in Learning Technology, 24, 1-17. http://doi.org/10.3402/rlt.v24.32036. Accessed 16 May 2017

Raffaghelli, J. E., Valla, S., Cucchiara, S., Giglio, A., \& Persico, D. (2014). Exploring researchers'discourses about producing, disseminating and evaluating scientific information on the web. The case of Biomedical Sciences. In L. Gómez-Chova, A. López Martínez, \& I. Candel Torres (Eds.), EDULEARN14 Proceedings (pp. 1701-1711). IATED. http://doi.org/ISBN 978-84617-0557-3. Accessed 16 May 2017

Ranieri, M. (2014). Le competenze digitali dei giovani ricercatori. Quadro teorico, modelli di analisi, proposte formative. Pedagogia Oggi, 1, 180-198.

Ren, X. (2013). Beyond open access: open publishing and the future of digital scholarship. In Proceedings of the 30th Australasian Society for Computers in Learning in Tertiary Education Conference (ASCILITE 2013).

Roemer, R. C., \& Borchardt, R. (2012). From bibliometrics to altmetrics: A changing scholarly landscape. Coll. Res. Libr. News, 73(10), 596-600.

Romero-Frías, E., \& Del-Barrio-García, S. (2014). Una visión de las humanidades digitales a través de sus centros. El Profesional de la Informacion, 23(5), 485-492. http://doi.org/10.3145/epi.2014.sep.05. Accessed 16 May 2017

Rons, N. (2011). Interdisciplinary Research Collaborations: Evaluation of a Funding Program. Collnet Journal of Scientometrics and Information Management, 5(1), 17-32. http://doi.org/10.1080/09737766.2011.10700900. Accessed 16 May 2017

Rumsey, A. S. (2011). New-Model Scholarly Communication: Road Map for Change. Retrieved from http://uvasci.org/ institutes-2003-2011/SCl-9-Road-Map-for-Change.pdf. Accessed 16 May 2017

Scanlon, E. (2014). Scholarship in the digital age: Open educational resources, publication and public engagement. British Journal of Educational Technology, 45(1), 12-23. http://doi.org/10.1111/bjet.12010. Accessed 16 May 2017

Simon, E., \& Pleschová, G. (2013). Teacher Development in Higher Education. Existing Programs, Program Impact and Future Trends. London: Routledge. 
Singh, G., \& Hardaker, G. (2014). Barriers and enablers to adoption and diffusion of eLearning: A systematic review of the literature a need for an integrative approach, Education \& Training 56(2/3), 105-121. http://doi.org/10.1108/ET-11-2012-0123. Accessed 16 May 2017

Steinert, Y., Mann, K., Anderson, B., Barnett, B. M., Centeno, A., Naismith, L., ... Dolmans, D. (2016). A systematic review of faculty development initiatives designed to enhance teaching effectiveness: A 10-year update: BEME Guide No. 40. Medical Teacher, 38(8). http://doi.org/10.1080/0142159X.2016.1181851. Accessed 16 May 2017

Stes, A., Min-Leliveld, M., Gijbels, D., \& Van Petegem, P. (2010). The impact of instructional development in higher education: The state-of-the-art of the research. Educational Research Review, 5(1), 25-49. http://doi.org/10.1016/j. edurev.2009.07.001. Accessed 16 May 2017

Stewart, B. E. (2015a). In abundance: Networked participatory practices as scholarship. The International Review of Research in Open and Distributed Learning, 16(3). http://dx.doi.org/10.19173/irrodl.v16i3.2158. Accessed 16 May 2017

Stewart, B. E. (2015b). Open to influence: what counts as academic influence in scholarly networked Twitter participation. Learning, Media and Technology, 40(3), 287-309. http://doi.org/10.1080/17439884.2015.1015547. Accessed 16 May 2017

Stewart, B. (2014). How do we know who we are when we're online?: Reputation, identity, and influence in scholarly networks. In R. T, S. Bayne, C. Jones, M. De Laat, \& C. Sinclair (Eds.), Proceedings of the 9th International Conference on Networked Learning (pp. 380-81). Lancaster: Networked Learning Conference.

Suber, P. (2009). Open-Access Timeline. Retrieved March 11, 2014, from http://legacy.earlham.edu/ peters/fos/timeline.htm. Accessed 16 May 2017

Teichler, U., Arimoto, A., \& Cummings, W. (2013). The Changing Academic Profession - Major Findings of a Comparative Survey. London \& New York: Springer.

Terras, M., Nyhan, J., \& Vanhoutte, E. (2013). Defining Digital Humanities: A Reader. London: Ashgate Publishing, Ltd.

Twining, P., Raffaghelli, J., Albion, P., \& Knezek, D. (2013). Moving education into the digital age: the contribution of teachers' professional development. Journal of Computer Assisted Learning, 9(5), 399-486. http://doi.org/10.1111/jcal.12031. Accessed 16 May 2017

Unsworth, J. (2013). What is humanities computing and what is not? In M. Terras, J. Nyhan, \& E. Vanhoutte (Eds.), Defining Digital Humanities: A Reader (pp. 51-65). London: Ashgate Publishing Ltd.

Valente, A. (2003). Trasmissione d'élite o accesso alle conoscenze? Percorsi e contesti della documentazione e comunicazione scientifica. Milano: Franco Angeli.

Veletsianos, G. (2012). Higher education scholars' participation and practices on Twitter. Journal of Computer Assisted Learning, 28(4), 336-349. http://doi.org/10.1111/j.1365-2729.2011.00449.x. Accessed 16 May 2017

Veletsianos, G. (2015). A Case Study of Scholars' Open and Sharing Practices. Open Praxis, 7(3), 199-209.

Veletsianos, G., \& Kimmons, R. (2012a). Assumptions and challenges of open scholarship. International Review of Research in Open and Distance Learning, 13(4), 166-189.

Veletsianos, G., \& Kimmons, R. (2012b). Networked Participatory Scholarship: Emergent techno-cultural pressures toward open and digital scholarship in online networks. Computers \& Education, 58(2), 766-774. http://doi.org/10.1016/ j.compedu.2011.10.001. Accessed 16 May 2017

Veletsianos, G., \& Kimmons, R. (2016). Scholars in an increasingly open and digital world: How do education professors and students use Twitter? The Internet and Higher Education, 30, 1-10. http://doi.org/10.1016/j.iheduc.2016.02.002. Accessed 16 May 2017

Veletsianos, G., \& Stewart, B. E. (2016). Discreet Openness: Scholars Selective and Intentional Self-Disclosures Online. Social Media + Society, 2(3), http://doi.org/10.1177/2056305116664222. Accessed 16 May 2017

Vescio, V., Ross, D., \& Adams, A. (2008). A review of research on the impact of professional learning communities on teaching practice and student learning. Teaching and Teacher Education, 24(1), 80-91. http://doi.org/10.1016/j.tate. 2007.01.004. Accessed 16 May 2017

Webster-Wright, A. (2009). Reframing Professional Development Through Understanding Authentic Professional Learning. Review of Educational Research, 79(2), 702739. http://doi.org/10.3102/0034654308330970. Accessed 16 May 2017

Weller, M. (2012). Digital Scholarship and the Tenure Process as an Indicator of Change in Universities. RUSC. Revista de Universidad y Sociedad del Conocimiento, 9(2), 167-182 347-360. http://doi.org/10.7238/rusc.v9i2.1398. Accessed 16 May 2017

Weller, M. (2011). The Digital Scholar: How Technology is Transforming Scholarly Practice. London: Bloomsbury Academic Wenger, E. (1999). Communities of Practice: Learning, Meaning, and Identity. Cambridge: Cambridge University Press. White, D. S., \& Cornu, A. Le. (2011). Visitors and Residents: A new typology for online engagement. First Monday, 16(9). Retrieved from http://firstmonday.org/ojs/index.php/fm/article/view/3171/3049. Accessed 16 May 2017

Zhao, L. (2014). Riding the Wave of Open Access: Providing Library Research Support for Scholarly Publishing Literacy. Australian Academic \& Research Libraries, 45(1), 3-18. http://doi.org/10.1080/00048623.2014.882873. Accessed 16 May 2017 